\title{
Male and Female Profanity in English Anecdotes
}

\author{
Anna Knyazyan \\ Yerevan State University
}

\begin{abstract}
The article covers the problem of profanity and deprecating humor in English anecdotes. Aggressive humor often occurs in the form of sarcasm or teasing and often includes compulsive displays of humor with little regard for others. It deals with the issue of using swearwords in comic discourse. Swearing is a behavior more frequently engaged in by males than by females. Various generalizations about women and men involve some false assumptions as they negate the aspirations, diverse identities and personalities of individual males and females. On the largest scale women are the brunt of more jokes than men.
\end{abstract}

Key words: gender roles, gender stereotypes, male, female, deprecating and disparaging humor.

\section{Introduction}

Profanity is a subject which generally calls forth many discussions and debates. On the largest scale this is partly due to the very nature of profanity, which is a part of what is generally called "bad language". This fact strongly suggests that bad language is a very general notion which is characteristic not only of profanity but also of other aspects of language i.e. slang, jargon, misuse. All linguistic studies of gender in language interdependent and complementary, but can identify several fundamental areas of linguistic research: sociolinguistic, social culture, psycholinguistic, communicative discourse. For studying male and female profanity qualitative and quantitative methodologies have been used which are still widely considered in the research methods. At a basic level, qualitative research commonly refers to the collection and analysis of material that seeks to uncover meaning and to promote the understanding of the experiences of the research subjects. By contrast, quantitative research is about the collection and analysis of numerical data - the social facts.

The current study has revealed that a high percentage of men make deprecating utterances targeted towards women. The problem of male power over women is very general and cross-cultural. Profanity refers to linguistic performances which 
are regarded as unacceptable by many people. In the broadest sense of the word bad language can be offensive and hurtful. Swearing is associated with bad education and behavior. As a rule, children who use swearwords are generally punished and reprimanded. Swearing seems to be a kind of speech present in every language, and also something which is part of the everyday life of many people. The exciting controversy of this kind of language is probably what makes it both captivating and shocking.

Every person takes on a particular role according to standards which are fixed in the society. Being a woman is closely linked with speaking "properly". Swearing is reserved to men only because women are not allowed to express any kind of control. Women are involved in everything that deals with the beginning of the life cycle. Males exert power on the public domain, on everything influential while female power is exerted on the private sphere. Women hold a disadvantageous role in society that is subordinate to that of men.

\section{Gendered Swearing in English Anecdotes}

In English society humor has a high visibility. It is expressed in various ways and can be found in everyday life. Many jokes about men are more positive in tone than jokes about women. There are categories of jokes about women for which there are no male parallels: prostitute anecdotes, mother-in-law anecdotes, blonde anecdotes. But in English anecdotes exclusively men use swearing to express anger and frustration. Swearing is gender-specific and is present in every language. The level of any offence of a swearword largely depends upon the situation and context in which it is used. It is striking to observe that the challenging aspect of this kind of language is probably what makes it both appealing and shocking in all senses.

Gender stereotypes are powerful means which serve to understand interactions between males and females. Stereotypes influence both the way men and women act and the way they speak. No doubt that gender has an impact on the vocabulary used when swearing. Swearing is another aspect of daily life where double standards exist: when men swear, it is mirthful or tough. When women do it, it is coarse and uncouth.

Linguistic behavior of males and females differ greatly. Females are more likely to use linguistic forms which are thought to be more correct than those used by males. According to Trudgill in any society females are generally more statusconscious than males, and therefore more sensitive to any linguistic norms. Working-class speech is very often associated with masculinity, which may lead 
males to be disposed to non-standard linguistic forms (Trudgill 1983). R. Lakoff claimed that language differences may be explained on the basis of female's subordinate social status (Lakoff 1975).

Traditionally men are viewed as bigger swearers, and women as prudish speakers, avoiding bad language. Disparaging humor has negative consequences. This fact strongly suggests that disparaging humor creates and reinforces negative stereotypes, prejudice, hostility towards females. Men and women have the same perception of what is obscene, but what differs is the quantitative use of these terms (Stapleton 2003). In English anecdotes women seem to know at least as much profanity and negative terms as men. But they do not use much profanity because of the stereotype of the silent and polite woman. In any society, speech patterns among males and females reflect the social and traditional stereotypes on men and women's nature and behavior (Sherzer 1987). So, if women are considered to be shy, this shyness will be expected to be found in their language. Sometimes this can lead to linguistic beliefs which are not asserted to be true, but which exist because of various socio-cultural stereotypes. Sometimes, females and males themselves try to conform to what is traditionally considered as a norm.

In English anecdotes men favor aggression to strengthen their authority, whereas women tend to display their knowledge by their choice of vocabulary. In anecdotes swearwords are classified into the following groups: 1) words relating to sexuality $\left.\left(f u c k^{1}, a s s^{2}, s h i t^{3}\right), 2\right)$ animal terms of abuse (pig, cow, bitch $\left.{ }^{4}\right), 3$ ) sexist terms of abuse (whore, slut), 4) intellect-based terms of abuse (idiot, prat, moron).

Words relating to sexuality are probably the most common and are part of the most used expletives. In this connection it should be noted that in English anecdotes males use the words fuck, shit, ass, much more frequently than females. Fucking is mainly used as an adjective or an adverb, that is to say, is often used in situations where the speaker wants to emphasize what he is saying. For example, a sentence like "that was a fucking nice wedding!" will have more impact on the listener than just "that was a nice wedding". Males mostly consider the word fuck as a binding factor (i.e. a close personal relationship that forms between them). It stems from the fact that men are not so strongly criticized and rejected as women, which proves that masculinity is an important factor of connection in male groups. The strongest interconnection between men can also be explained by the fact that the need for recognition through boasting is important among men. It is regarded as 
a sign of their strongest attachment. This integrity may be accounted for by the fact that the use of swearwords is considered as "strong" language.

Swearwords (invectives) are also connected to religion. Swearing also sometimes refers to the Christian religion with expletives like "Jesus", "Hell", "God". Religion is another domain once reserved to men only because in the Bible, Jesus, the central element of the Christian religion was a man, as well as all of his Apostles.

In English anecdotes words like God, hell, Jesus, Christ, damn, damned are generally considered as blasphemous. For example:

A young girl went into confession and told the priest she had slept with four different men over the past week. Jack on Tuesday, Bill on Wednesday, Peter on Thursday and Chuck on Friday.

"Well my child" said the priest "on your way home tonight buy two lemons and suck on them."

"But Father, will that cleanse me of my sins?" she asked.

"No, but it'll take that bloody damned smile off your face."

(Sharpe 2004:142)

Animal abuse alludes to words like bitch, cow, pussy, monkey, animal, bull, (dead) cat, dog, sheep, hen, cock, chicken. In English anecdotes bitch is the word males use most. It should be added in this connection that bitch is mainly used to refer to women in a derogatory way. As men are generally not called bitches, this word is referred to women only. Cow is a pure intragender word for females; this does not appear to be the case for males. All the facts are in favor of the belief that in English anecdotes women are targets of deprecatory humor. Deprecatory humor has social consequences on women. It affects the ways that men think about women and perceive discrimination against them.

For example:

A husband and wife sleep in separate twin beds. One night he asks his wife to come over to his bed to fool around.

As the wife gets up to walk over to his bed, she trips over the carpet and falls flat on her face. The husband looks up concerned and says, "Oh did my little wifey fall on her little nosey wosey?" 
She laughs and gets in his bed. When they are done, she gets up to go back to her bed and falls over the rug again. Her husband looks over his shoulder to see her on the floor, rolls over and says, "Clumsy bitch."

(Some Funnies 2015)

There can be no doubt that people jokingly call others bitch, stupid, loser, silly, foolish or fool to assert their place within the social status hierarchy. In many cases when these words are said with a chortle, they seem less unkind, cruel, uncivil and more acceptable. But it does not mean that people particularly enjoy hearing them.

Men use substantially more swearwords when they are with other men.In English anecdotes men consider profanity as a much more gender related feature, avoiding this kind of language with women, but using it a lot more with other men, especially in certain situations, like sports. Males have a preference for "stronger" word forms while females have a preference for 'weaker' word forms. For example:

A boy comes home one day and runs up to his mom.

"What's a bitch and a pussy?"

"Well," Mom says, "a bitch is a female dog and a pussy is a cat." The boy thinks to himself that this doesn't sound right since the other kids were calling each other that. So he goes to Dad.

"What's a bitch and a pussy?" Dad pulls out his Playboy and opens it to the centerfold. He draws a circle around the woman's pussy.

"Now that's a pussy, son! And everything else is the bitch!"

(Some Funnies 2015)

A closer look at this phenomenon supports the view of limited access to sexually explicit discourse by women. Hesitations, pauses and silences mark difficulties that the women come across in answering sensitive questions. The anecdote about a woman and a police officer illustrates this difficulty. In women's speech hesitations are very often accompanied by muttering and mumbling,

Police officer: What did he then do? Tell us everything that happened. 
Woman: After he lay on top of me, he parted my legs, and pushed his thing inside me.

Police officer: What thing did he push inside you? I want to repeat that you have to tell us everything and you should use adult and not childish language; it is not my fault but the law requires that you tell us everything.

Woman: um ... [silence]

Police officer: Are you going to tell us what this man did to you or what? We cannot stay here the whole day. We have other important things to do.

Woman: [sobbing]: He pushed his pipe, his [inaudible] inside my cake...

Police officer: [interrupts]: What? [laughs out loud] You seem to be very stubborn. Being stubborn does not work in cases like these.

Woman: He pushed his thing here [demonstrates by placing her hand between her thighs].

Police officer: I don't think you understand what I am saying. You are a woman and not a girl, according to this medical report. The doctor clearly points out that you did not suffer any

injuries during the sexual intercourse. Isn't it?

Woman: [silence]

(Sharpe 2004:59)

In the anecdote above, the woman refers to her assailant's penis as his thing, his pipe and toher vagina as my cake - using a code for women. While police officer mostly uses the sexually explicit expression (sexual intercourse), and demands that the woman does the same but the latter sticks to the use of euphemisms. The police officer asks questions mainly on sexual issues. The male marked words are more offensive, more potent, than the female marked words.

Our study has revealed that there is a set of swearwords which are used with an exclusive gender direction either by male speakers or by female speakers. 
Table 1

\begin{tabular}{|c|c|c|}
\hline & Female targets & Male targets \\
\hline fuck & 54 & 33 \\
\hline fucked & 6 & 15 \\
\hline bloody ${ }^{5}$ & 25 & 89 \\
\hline bastard & 0 & 30 \\
\hline wanker & 0 & 10 \\
\hline cunt $^{6}$ & 2 & 16 \\
\hline arse & 4 & 30 \\
\hline bugger & 0 & 20 \\
\hline shit & 10 & 5 \\
\hline piss $^{7}$ & 3 & 24 \\
\hline bird & 10 & 0 \\
\hline gay & 0 & 10 \\
\hline sod & 0 & 11 \\
\hline arsehole & 0 & 11 \\
\hline idiot & 0 & 10 \\
\hline cow & 30 & 0 \\
\hline$g i t^{8}$ & 0 & 10 \\
\hline bitch & 56 & 0 \\
\hline cunt & 0 & 8 \\
\hline big-ass & 10 & 0 \\
\hline tart & 5 & 0 \\
\hline whore & 10 & 0 \\
\hline tits & 9 & 0 \\
\hline slag & 10 & 0 \\
\hline
\end{tabular}

In English anecdotes the words themselves seem to display some evidence of being directed quite differently by males and females. There are words which show a strong gender targeting, preference by males or females but which are not gender exclusive. The words like cow, bitch, bloody, fucking, slag, tart, tit, tits and whore are directed at females by females, bastard, gay, cunt, idiot are used by females, which are directed exclusively at males. Fucking, bloody, bastard, wanker, cunt, arse, fucked, piss, gay, sod, arsehole are directed at males by males. 
It is deducible from what has been said above, that there are several ways one can use language to hurt or express frustration. "Women's language" reflects powerlessness and this is the reason why a woman swearing is classified or described as disgraceful. Traditional stereotypes tend to represent women as people who avoid swearing. Women do not have the same tools as men to affirm themselves (that is, "strong language"). This fact strongly suggests that they often develop different practices to reinforce their in-group recognition in English anecdotes. In interactions women avoid any confrontation. But there are cases when women use more profanity than men. It then appears that women seem to know at least as much profanity and negative terms as men. For example:

A dude comes home from work one day, and his wife is watching the Food Network. The husband asks, "Why do you watch that? You still can't cook," and the wife responds, "Why do you watch porn? You still can't fuck."

(Bigfun com. 2015)

Watching his wife put her bra on, the man sneered, "I don't know why you bother, it's not as if you've got anything to put in it."

"Bugger off," she replied. "I don't complain when I'm ironing your underpants."

(Sharpe 2004:126)

There are several ways one can use language to hurt, be obscene or express frustration. However, even if, generally speaking, everyone shares the same conception of what swearwords are, everyone does not react equally as far as profanity is concerned. Some people will be profoundly offended when hearing "fuck", but some people will use it many times a day in casual conversations with friends. Some people will be disgusted by a woman saying "shit", but these people may not even notice it when used by a man. Some people never swear in public, or at work, but will be extremely vulgar at home. That is to say, everyone has a different degree of tolerance regarding profanity, and everyone uses it differently according to the context. 


\section{Conclusion}

Perhaps it is most reasonable to conclude that in English anecdotes women's and men's linguistic strategies differ according to the situation they are in, as well as according to the people they are talking to. But the observation of the facts reveals that sociocultural stereotypes on language and gender could be questioned, since our research showed that women's supposed prudishness is very relative, and that men can be a lot more than women likely to avoid swearing in certain situations. However, it should be emphasized once again that in English anecdotes men's voice dominates. The fact that swearing is gender-related and serves to reinforce social status leads us into a notion that traditional stereotypes are still present in English society.

\section{Notes:}

1. The most popular origin story of fuck goes something like this - after the great plague the English population was considerably downsized, so the King ordered his people to reproduce. Hence, fuck is "Fornicate Under Command of the King”. <http://www.storypick.com/swear-word-origins $>$.

2. This word has its roots in the Old English word assa, and since the medieval era people started associating it with a "stupid" person (like a donkey). As for the use of the word to mean backside - it came from Old English cers, which meant buttock. <http://www.storypick.com/swear-word-origins>.

3. This word comes from Old English word scitte, meaning purging or excrement. The poet Robert Frost created the word Shitticism to mean scatological writing. $<$ http://www.storypick.com/swear-word-origins $>$.

4. The word bitch comes from Old English word bicce, which also meant female dog. But since 1400, the use of this word to signify "a lewd or immoral woman" came to be. It is the most offensive appellation that can be given to an English woman. <http://www.storypick.com/swear-word-origins>.

5. This utterly common swearword is believed to be a corruption of the exclamatory phrase 'by your lady'. The Oxford English Dictionary also suggests that it derives from a reference to the aristocratic rowdies (who had royal blood) of the Restoration period. $<$ http://www.storypick.com/swear-wordorigins $>$. 
6. This word derives from the ancient Sumerian word kunta which meant female genitalia. It was also spelled "quna," which is the root of the word queen. $<$ http://www.storypick.com/swear-word-origins $>$.

7. This mild swearword originates from Latin pissare and French pissier both of which describe the sound of urination. $<\mathrm{http}$ ://www.storypick.com/swear-wordorigins $>$.

8. It actually is a variation of the commonly used word get, and has been in use since the $14^{\text {th }}$ century. But even get comes from shortening beget, referring to the idea of illegitimate pregnancies and resulting offsprings.

$<\mathrm{http}: / /$ www.storypick.com/swear-word-origins $>$.

\section{References:}

1. Lakoff, R. (1975) Language and Women's Place. New York: Harper and Row.

2. Stapleton, K. (2003) Gender and Swearing: A Community Practice. // Women and Language, 26 (2), pp. 22-33.

3. Sherzer, J. (1987) A Diversity of Voices: Men's and Women's Speech in Ethnographic Perspective. // Language, Gender and Sex in Comparative Perspective. / Ed by. S.U. Philips, S. Steele, Ch. Tanz. New York: Harper and Row, pp. 95-120.

4. Trudgill, P. (1983) Sociolinguistics: An Introduction to Language and Society. Harmondsworth: Penguin Books.

\section{Sources of Data:}

1. Bigfun com. Available at: <http://www.laughfactory.com/jokes/boycott-thesejokes/3> [Accessed August 2015].

2. Sharpe J. (2004) The Adult Joke Book. London: Arcturus Publishing Limited.

3. Some Funnies. Available at: <http://jokes4reallaugh.blogspot.com/2013/06/ man-at-bed time.html $>$ [Accessed August 2015]. 


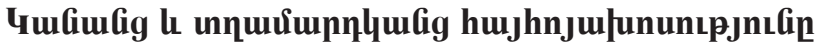 ufiqthulquei ufitipnnunfiknnux}

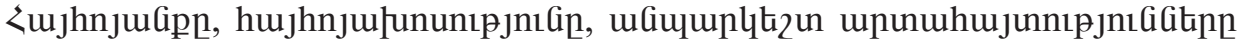

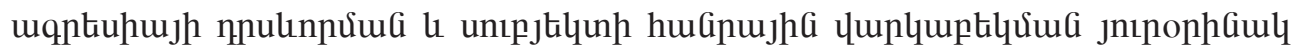

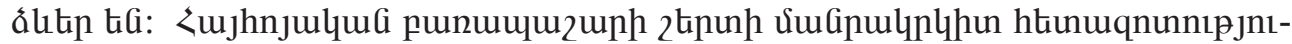

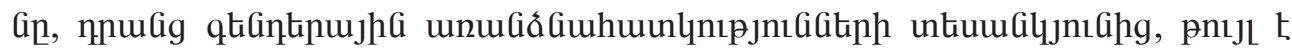

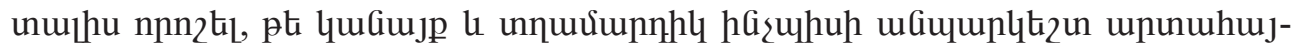

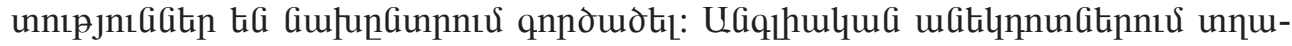

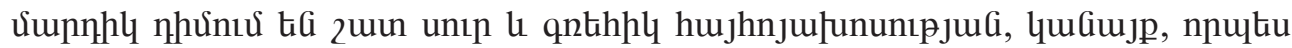

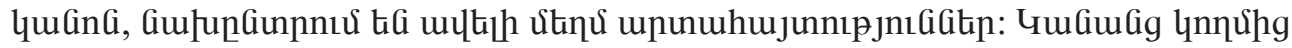

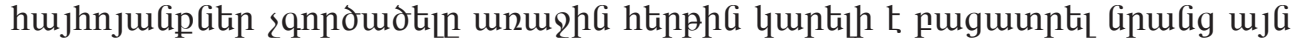

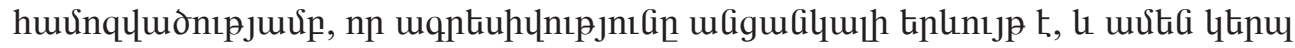
ulinp t. funtumutil nnwaihg: 